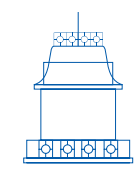

ARTÍCULOS

DE INVESTIGACIÓN

\title{
Beyond instrumental rationality. For a critical theory of freedom*
}

\author{
Jana Katharina Funk \\ University of Bamberg, Bamberg, Germany \\ E-mail: jana.funk@posteo.de
}

Recibido: 14 de diciembre de 2019 | Aprobado: 30 de marzo de 2020

https://doi.org/10.17533/udea.ef.n63a05

\begin{abstract}
This article will provide an illustration of Max Weber's theory of rationalization with a specific impetus on its interdependency with the development of capitalism. Following Horkheimer, I shall critically draw on Weber to outline a theory of human freedom, showing that rationalization not only implies economic and social liberation but entails a totalizing tendency that invades all spheres of socio-political life including people's mental infrastructure. This mental colonization can be framed as a process of substituting value rationality with instrumental rationality. I will claim that this substitution can be understood as an impediment for human freedom. Following contemporary theories of action (Anscombe, Foot), I will show the centrality of value orientation for understanding human freedom. Therefore, I propose a critical theory of freedom that centers value rational action as realization of freedom and can be understood as emancipative.
\end{abstract}

Keywords: Critical Theory, human freedom, rationalization, instrumental rationality, value rationality, critique of capitalism

* This paper is part of my investigation for my doctoral thesis in political philosophy at the University of Bamberg, Germany.

Cómo citar este artículo:

Funk, J. (2021). Beyond instrumental rationality. For a critical theory of freedom. Estudios de Filosofía, 63, 91-108. https://doi.org/10.17533/udea.ef.n63a05 


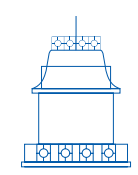

ARTÍCULOS

DE INVESTIGACIÓN

\title{
Más allá de la racionalidad instrumental. Hacia una teoría crítica de la libertad
}

\begin{abstract}
Resumen: Este artículo dará una ilustración de la teoría de racionalización de Max Weber con un énfasis específico en su interdependencia con el desarrollo del capitalismo. Siguiendo a Horkheimer, recurriré críticamente a Weber para esbozar una teoría de la libertad humana, mostrando que la racionalización no solo implica la liberación económica y social, sino que conlleva una tendencia totalizadora que invade todas las esferas de la vida sociopolítica, incluida la infraestructura mental de las personas. Esta colonización mental puede enmarcarse como un proceso de sustitución de la racionalidad del valor con la racionalidad instrumental. Sostendré que esta sustitución puede entenderse como un impedimento para la libertad humana. Siguiendo las teorías contemporáneas de acción (Anscombe, Foot), mostraré en detalle la centralidad de la orientación de valores para comprender la libertad humana. Por lo tanto, propongo una teoría crítica de la libertad que se centra en el valor de la acción racional como la realización de la libertad y que puede entenderse como un potencial transformador.
\end{abstract}

Palabras clave: Teoría crítica, libertad humana, racionalización, racionalidad instrumental, crítica al capitalismo

\section{Jana Katharina Funk}

Es doctorante en la universidad de Bamberg, Alemania. Estudió filosofía, ciencia política y estudios asiáticos en Berlín, Nueva Delhi y Bamberg. Durante sus estudios, ha sido investigadora visitante en la Universidad de Buenos Aires, Argentina, y la Universidad De Paul, Chicago. Sus intereses investigativos están relacionados con la justicia global, el liberalismo, la teoría moral y los estudios feministas. 


\section{Introduction: a critical theory of freedom}

In this article, I argue for a critical theory of freedom that has the potential to unfold a transformative potential. Systematically speaking, there are two ways in which a theory can be critical. (1) It can be critical in the sense of reflexive criticism and (2) it can be critical through offering theoretical foundations to frame a critique of social injustice, power relations and structural violence that hinder people in living up to their individual potentialities. As for the first point (1), it refers to the reflexive component of critical theory: its fierce commitment to epistemic vigilance. Epistemic vigilance involves a threefold reflexivity: (A) subjective reflexivity, as awareness of epistemic boundaries that are connected to the process of thinking; (B) methodological reflexivity, for, as being part of the scientific community, the search for knowledge is connected to scientific methods of thinking and writing; and (C) standpoint reflexivity, because, as a person theorizing, my perspective is amenable to a certain standpoint that is itself embedded in cultural, social and structural specificities. I do acknowledge the importance of reflexive criticism. Yet, in this article, I shall focus on the second aspect in which a theory can be critical and with that, I create a link back to Max Horkheimer and the Frankfurt school of social thought. Therefore, I refer to the commitment of expressing the shortcomings of modern moral universalisms: the promise to accredit freedom and equality to all members of humanity. In his famous essay Traditional and critical theory, Max Horkheimer characterized the critique of critical theory in the following way:

To that extent, the critical theory is the heir not only of German idealism, but of philosophy as such. It is not just a research hypothesis which shows its value in the ongoing business of men; it is an essential element in the historical effort to create a world which satisfies the needs and powers of men. However extensive the interaction between the critical theory and the special sciences whose progress the theory must respect and on which it has for decades exercised a liberating and stimulating influence, the theory never aims simply at an increase of knowledge as such. Its goal is man's emancipation from slavery. In this it resembles Greek philosophy, not so much in the Hellenistic age of resignation as in the golden age of Plato and Aristotle. After the fruitless political projects of both these men the Stoics and Epicureans confined themselves to developing a doctrine of individualistic practices. The new dialectical philosophy, however, has held on to the realization that the free development of individuals depends on the rational constitution of society. In radically analyzing present social conditions it became a critique of the economy (Horkheimer, 1972, p. 245f).

Thus, it is clear that critical theorizing does not understand human development as an abstract notion that is independent from society or political communities as such. The critique is always a political question that presupposes understanding of the political; including the political economy, the political order, and the political nature of human beings. 
Even though critical theory is the heir of German idealism, as Horkheimer pointed out, it does not exhaust itself in historical materialism. Critical theory, if it is to be understood in the tradition of the Frankfurt school, does not question humans' capacity of spontaneity. Humans are not only acting out roles according to the structural, social-political frames given to them through socialization, but can also be authors of themselves, their own lives as well as the world around them. As authors, humans can actually bring about structural changes through changes of consciousness. A critical theorist may claim that emancipation can be inspired appealing to moral universals, or let's say, through idealist thinking in connection to a fierce criticism of structural impediments; whether they are of social, political or economic nature:

The critical theory, on the contrary, having the happiness of all individuals as its goal, does not compromise with continued misery, as do the scientific servants of authoritarian States. Reason's intuition of itself, regarded by philosophy in former times as the highest degree of happiness, is transformed in modern philosophy into the materialist concept of a free, self-determining society, while retaining from idealism the conviction that men have other possibilities than to lose themselves in the status quo or to accumulate power and profit (Horkheimer, 1972, p. 248).

I have stated that I will argue for a critical theory of freedom. Against the background of what has been said, a critical theory of freedom means acknowledging the claim that human freedom is the main goal of emancipation. Furthermore, a critical theory of freedom recognizes the materialist insight (1) that human freedom is directly connected to free societies, and the idealist insight (2) that freedom does not exhaust itself in the accumulation of materiality or power. In the following reflections, I want to focus on both of these aspects. As far as the materialist insight is concerned, I shall analyze the process of modernization. I draw on Max Weber in trying to work out modernity's movens, the interdependency of rationalization and the capitalist economy with its inscribed dynamic to diffuse instrumental thinking; a dynamic that further potentiates itself even as a colonization of people's lifeworlds (Habermas, 1982, p. 471).

In this article, my intention is to show that this very inbuilt dynamic of rationalization is an impediment for human freedom, as has been outlined by the Frankfurt school. Beyond that well-known thesis, drawing on an outline of a theory of action, I will argue that through the expansion of capitalist thinking and acting, freedom has been primarily framed through instrumental rationality - a development that undermined the importance of value rationality. Against the background of the colonizing tendency of instrumental thinking, I claim that the notion of value oriented human freedom must be constantly fought for -even more so in the world of a highly developed capitalism. Finally, I intend to frame value rational activity, not only as an integral part of critical theory, but also as an emancipative endeavor. 


\section{Rationalization and capitalism}

Starting with an outline of a theory of modernization, I use Max Weber's insights regarding the dynamics of rationalization in connection with the development of a capitalist economy. For Weber, capitalism is to be understood as an output of different components of rationalization merging together. In his late work General economic history, a collection of lectures delivered in the winter semester of 1919/20, he even frames the entire economic history as the history of rationalization (Weber, 1923, p. 15). Hence, to understand this affirmation, it is important to elucidate the major components of rationalization according to Weber. In The Protestant ethic and the spirit of capitalism (2005), Weber illustrates the important role of cultural rationalization through the medium of Protestantism in the $16^{\text {th }}$ and $17^{\text {th }}$ century in central Europe. In the most famous expression of the disenchantment of the world, Weber's theory of cultural rationalization through Protestantism finds its concise articulation:

The rationalization of the world, the elimination of magic as a means to salvation, the Catholics had not carried nearly so far as the Puritans (and before them the Jews) had done. To the Catholic, the absolution of his Church was a compensation for his own imperfection. The priest was a magician who performed the miracle of transubstantiation, and who held the key to eternal life in his hand. One could turn to him in grief and penitence. He dispensed atonement, hope of grace, certainty of forgiveness, and thereby granted release from that tremendous tension to which the Calvinist was doomed by an inexorable fate, admitting of no mitigation. For him such friendly and human comforts did not exist. He could not hope to atone for hours of weakness or of thoughtlessness by increased good will at other times, as the Catholic or even the Lutheran could. The God of Calvinism demanded of his believers not single good works, but a life of good works combined into a unified system. There was no place for the very human Catholic cycle of sin, repentance, atonement, release, followed by renewed sin. Nor was there any balance of merit for a life as a whole which could be adjusted by temporal punishments or the Churches' means of grace (Weber, 2005, p. 71).

Cultural rationalization as disenchantment of the world can be understood as fostering cognitive framing through methods of natural science. Accordingly, contrary to an understanding of the world being guided by obscure and spirited laws, the modern world view tends to understand the world as a system that can eventually be explained through the scientific framework of cause and effect in which human action can be controlled and modified as a variable in a mathematical equation:

The moral conduct of the average man was thus deprived of its planless and unsystematic character and subjected to a consistent method for conduct as a whole. It is no accident that the name of Methodists stuck to the participants in 
the last great revival of Puritan ideas in the eighteenth century just as the term Precisians, which has the same meaning, was applied to their spiritual ancestors in the seventeenth century (Weber, 2005, p. 71).

The cultural rationalization that pointedly occurred through Protestantism can comprehensively be interpreted as a rational systematic configuration of people's moral life. Its effect was not just calculability, but also liberation; a liberation from immediate dependency of nature and its inbuilt physical stimuli. The cultural rationalization installed man as its own master over the course of his life, allowing him to be his own rational cause of a flourishing and moral life (Weber, 2005). Although this liberation and abstraction from the world allowed unprecedented control, it came along with the permanent calling towards self-control and rational life conduct. As such, according to Weber, disenchantment can be understood as the very beginning of an antinomian dynamic present in rational modernity: liberation and the excessive demand of instrumental rationality over people's lives. However, for the explanation of the rise of capitalism in occidental societies, Weber points out another factor of rational Protestantism. The structural order of moral life also flew into the idea of an inner-worldly virtue: The idea of a calling.

Christian asceticism, at first fleeing from the world into solitude, had already ruled the world which it had renounced from the monastery and through the Church. But it had, on the whole, left the naturally spontaneous character of daily life in the world untouched. Now it strode into the market-place of life, slammed the door of the monastery behind it, and undertook to penetrate just that daily routine of life with its methodicalness, to fashion it into a life in the world, but neither of nor for this world (Weber, 2005, p. 101).

The idea of this inner-worldly calling (Beruf) has an unmistakable religious aspect: to fulfill God's duty in humans' temporary existence. Weber saw in this Protestant conception of the worldly calling nothing less than "the valuation of the fulfilment of duty in worldly affairs as the highest form which the moral activity of the individual could assume" (Weber, 2005, p. 40).

The worldly duty would emerge as a daily activity with religious significance and a morally connoted indispensable task for a pious man. To secure God's grace one had not primarily to aspire to cultivating spiritual virtues, but to work towards fulfilling one's deeds in the finite world. God's glory was to be increased through embracing the creaturely humaneness -its dammed and short life span. As time was precious, the more rationale had to flow into using it wisely: "Loss of time through sociability, idle talk, luxury, even more sleep than is necessary for health, six to at most eight hours, is worthy of absolute moral condemnation" (Weber, 2005, p. 104).

There, as Weber himself mentioned, Benjamin Franklin's "Time is money" is not far-fetched (Weber, 2005, p. 104). It was the rational method of living one's life, that 
consequently became a means to praise God - a logic that in fact can be understood as the cornerstone of the standardization and uniformation of life, that determines today's capitalist societies. Of course, the roots of this emerging spirit of capitalism reaches as far back as the Middle Age, yet, according to Weber, it was Protestantism that further furnished human history with its very ethical underpinning: a rational method of life-organization (Weber, 2005, p. 115).

A specifically bourgeois economic ethic had grown up. With the consciousness of standing in the fullness of God's grace and being visibly blessed by Him, the bourgeois business man, as long as he remained within the bounds of formal correctness, as long as his moral conduct was spotless and the use to which he put his wealth was not objectionable, could follow his pecuniary interests as he would and feel that he was fulfilling a duty in doing so. The power of religious asceticism provided him in addition with sober, conscientious, and unusually industrious workmen, who clung to their work as to a life purpose willed by God. Finally, it gave him the comforting assurance that the unequal distribution of the goods of this world was a special dispensation of Divine Providence, which in these differences, as in particular grace, pursued secret ends unknown to men. Calvin himself had made the much-quoted statement that only when the people, i.e. the mass of laborers and craftsmen, were poor did they remain obedient to God (Weber, 2005, p. 120).

With this economic ethic emerged an embedded legitimization of exploitation and productivity, which was per se indefeasible, as it originated within the grounds of transcendence. Given that, the rational ethos needs to be understood as to be more than a mere underpinning of capitalism.

In fact, it is more like an insurmountable cosmos, whose unwritten laws are provenance and destination of a normative understanding of the world. Qua human being, one has to accept and cultivate its innate patterns of thinking and behavior. And there, Benjamin Franklin not only appears through association of thought, but as a foundation of this very ethos: the spirit of capitalism and its iron cage of rationality (Weber, 2005) A cage that can, metaphorically speaking, be represented as a normative frame of utility-totality in which all human virtues and even human freedom are presented as sacrifices to the all-pervasive calling to instrumental functionality. The denominated cultural rationalization is more than a mere underpinning -it has to be understood as a veiled movens of capitalism and the ever-ongoing rationalization of life. As we have seen, rationalization itself is not to be understood as a curse, nor as a simple blessing -according to Weber, it is a necessary force of modernization, liberation and affluence. However, in the course of time, the dynamic of normative functionalization has become its own end, legitimized through cross reference to a transcendental source.

As such, the interdependency of rationalization and capitalistic development is clear: the history of economy is not to be understood beyond the process of cultural 
rationalization, rather, capitalism is inextricably dependent of a rationalized ethos. Therefore, capitalism and rationalization were being created as ends in themselves. In Weber's phrasing, capitalism finds its end in its method of enterprise, a denomination that can be translated into the idea of accumulation:

Capitalism is present wherever the industrial provision for the needs of a human group is carried out by the method of enterprise, irrespective of what need is involved. More specifically, a rational capitalistic establishment is one with capital accounting, that is, an establishment which determines its income yielding power by calculation according to the methods of modern bookkeeping and the striking of a balance (Weber, 1950, p. 275).

Disconnected from the actual needs or values of people, capitalism hence created its own value system of productivity, functionality and rationality; a parallel value system to moral values that is still characteristically present in capitalism of the $21^{\text {st }}$ century. Given that, Weber was right in his analysis of the origins of occidental capitalism. For Weber, beyond the broader expansion of cultural rationalization, there are six particular structural presuppositions for the development of capitalism's essence:

(1) Rational capital accounting,

(2) a free market-system,

(3) rationalizing technology,

(4) rational law,

(5) a free labor market and

(6) the commercialization of economic life (Weber, 1950, p. 277).

Following up on these structural presuppositions, it is clear that there is a causal commonality to all of them: the rational cosmos. In his monograph on Weber and Marx, Karl Löwith found the following expression:

Weber did not regard capitalism as a power made up of 'relations' of the forces and means of production which had become autonomous, so that everything else could be understood therefrom in terms of ideology. According to Weber, capitalism could only become the 'most fateful' power in human life because it had itself already developed within the framework of a 'rational way of life'. The 'rationality' which is claimed as a principle of understanding is thus not only the rationality of something-the rationality of a certain domain (which then also acts as a 'determinant' for other areas of life) (Löwith, 2003, p. 63).

The insurmountable rational cosmos becomes a totality -that does not leave an any room beyond it (Löwith, 2003, p. 63). Of course one needs to be precise before criticizing the totality of rationalization, for as human beings are rational animals, their very nature calls them to act in line with rationality. Given that, it is not rationality as 
such that is being criticized, but a particular type of rationality; namely instrumental rationality. In his action theory, Weber generally differentiated four types of human action rationality. It may be (1) instrumentally rational, (2) value-rational, (3) affectual and (4) traditional (Weber, 1978). Because of the claim I am defending here that rationalization and capitalism are reducing human freedom to instrumentality, pushing back value orientated human action, I will merely focus on the first two. For Weber, instrumentally rational human action is "determined by expectations as to the behavior of objects in the environment and of other human beings; these expectations are used as "conditions" or "means" for the attainment of the actor's own rationally pursued and calculated ends. "'Value rational human activity is one' that is determined by a conscious belief in the value for its own sake, some ethical, aesthetic, religious, or other form of behavior, independently of its prospects of success" (Weber, 1978, pp. 24-25). It is important to mention, that Weber did not argue in a pointedly normative manner; his very sociological analysis was characterized by the attempt to stay objectively descriptive. Clearly, as Karl Löwith did, one might argue that Weber's theory can be read as an implicit critique (through notions like the iron cage); however, he did not provide a normative philosophical criticism.

Yet, the critique of instrumental rationality that has been picked up and further developed by Horkheimer and Habermas was already present in Weber's theoretical framework:

The peculiar irrationality formed within the process of rationalization, and which is the real motive for the investigation of this process, also appears to Weber in terms of this relation between means and ends, which for him is the basis for the concepts of rationality and freedom-namely, in terms of a reversal of this relation. That which was originally a mere means (to an otherwise valuable end) becomes itself an end or an end in itself (Löwith, 2003, p. 68).

Löwith's claim is very important for my argument. Its essence comes down to a particular shift in the means to end relation in the use of rationality. In a normative framework of human action, that was understood as value rational, rationality was comprehended as a means to promote human freedom. Yet, in the course of capitalist development, rationality was reduced to instrumental rationality and became an end to itself, a process that can even be framed as irrationality. It is irrational, as it has lost its former rational end: human freedom. A critical theory of freedom would have to take this insight into account, proposing a differentiated theory of freedom that incites transformative power.

\section{Totalization of instrumental rationality}

It was Horkheimer who picked up on Weber's theory of rationalization, using it as a framework for a critical social theory. In his monographs Eclipse of reason and Critique 
of instrumental reason (2012), he develops a critique through an analytic account of rationality across the history of ideas. With regard to Horkheimer's ideas, there are three points I would like to accentuate: (1) the process of reducing rationality to the reflection about how to achieve a subjective, egoistic end (instrumental reductionism); (2) the loss of an objective grounding of rationality; and (3) the thrashing of the individual. These points are essential to understanding the thesis of the loss of freedom in a broader context of the history of ideas that I shall further pick upon.

(1) Instrumental reductionism

With the composite "instrumental reductionism", I refer to the process of the articulated shift in the means to end relation in the use of rationality. It is a reductionism. As in the course of modernization, rationality was -in its primary power to define ends - reduced more and more as an instrument to define the best means to achieve a particular end. More so, beyond the instrumentalization of human rationality as such, Horkheimer denotes the tendency of instrumentality taking over people's lives as such, rendering it completely obligated to the totality of rationalization:

Man has gradually become less dependent upon absolute standards of conduct, universally binding ideals. He is held to be so completely free that he needs no standards except his own. Paradoxically, however, this increase of independence has led to a parallel increase of passivity. Shrewd as man's calculations have become as regards his means, his choice of ends, which was formerly correlated with belief in an objective truth, has become witless: the individual, purified of all remnants of mythologies, including the mythology of objective reason, reacts automatically, according to general patterns of adaptation. Economic and social forces take on the character of blind natural powers that man, in order to preserve himself, must dominate by adjusting himself to them (Horkheimer, 2004, p. 66).

It is clear that rationalization has not only enabled liberation from traditional bonds - whether of social, political or economic nature- but has further opened up the horizon of human action; yet, human freedom shall not be exhaustively understood as a multiplication of means.

(2) Loss of objective grounding of rationality

Instrumental reductionism of rationality is embedded in a process of individualization across the history of ideas. Through secularization and the accompanying loss of religious authority, rationality was put in a secular context of interpretation; without the normative background of the religious value system, it was being left to self-reference. On the one hand, rationality was liberated from bonds, on the other hand, it was left to normative insecurity and accordingly to normative crisis. Kant certainly tried to solve this crisis through rationality itself. But since Kant's critical transcendentalism, modern philosophy seems to have given up the search for an objective grounding of values. For Horkheimer, this process led to modern pragmatism, substituting the search for 
truth and possible groundings of objective value, to the logic of probability, aspiring the defined end of a possible satisfaction of the individual (Horkheimer, 2004).

In pragmatism, pluralistic as it may represent itself to be, everything becomes mere subject matter and thus ultimately the same, an element in the chain of means and effects. Test every concept by the question "What sensible difference to anybody will its truth make?" and you are in the best possible position for understanding what it means and for discussing its importance (Horkheimer, 2004, p. 32).

Across the history of ideas, rationality consequently was not only reduced to being a mere instrument to finding means, but man himself had sacrificed himself in defining rationality as being nothing more than a possible tool to satisfy subjective needs. Self-interest had become a hegemonic principle. (Horkheimer, 2007).

(3) Thrashing of the individual

Ultimately, the crisis of rationality is to be understood as a crisis of the individual (Horkheimer, 2004). With rationality becoming subjective, the subject itself is not needed any more. If rationality is reduced to a mechanism of finding the best means, then processes of rationalization were being taken over by proceduralism. In the totality of a rationalized world, the individual is more and more subordinated by its own rationalized objective to self-indulgence:

It is not technology or the motive of self-preservation that in itself accounts for the decline of the individual; it is not production per se, but the forms in which it takes place -the interrelationships of human beings within the specific framework of industrialism. Human toil and research and invention is a response to the challenge of necessity. The pattern becomes absurd only when people make toil, research, and invention into idols. Such an ideology tends to supplant the humanistic foundation of the very civilization it seeks to glorify. While the concepts of complete fulfilment and unrestrained enjoyment fostered a hope that unshackled the forces of progress, the idolization of progress leads to the opposite of progress. Arduous labor for a meaningful end may be enjoyed and even loved. A philosophy that makes labor an end in itself leads eventually to resentment of all labor. The decline of the individual must be charged not to the technical achievements of man or even to man himself-people are usually much better than what they think or say or do-but rather to the present structure and content of the 'objective mind/ the spirit that pervades social life in all its branches. The patterns of thought and action that people accept ready-made from the agencies of mass culture act in their turn to influence mass culture as though they were the ideas of the people themselves. The objective mind in our era worships industry, technology, and nationality without a principle that could give sense to these categories; it mirrors the pressure of an economic system that admits of no reprieve or escape (Horkheimer, 2004, pp. 103-104). 
Horkheimer's take on the process of rationalization is harsh: it has reduced the human world to a world of means. Thus, the paradoxical nature of modernity becomes even more explicit; evidently, rationalization does inspire liberation (from traditional bonds, economic dependency, political submission...etc.), but without a critical examination of these dynamics of liberation, rationalization necessarily implies further threats to human freedom. In the totality of an instrumentally rational world, human ends are being reduced either to a stimuli-response reaction or to subjective calculation. Individuals become instruments of their desires, or their successful scheming. For Horkheimer, this is nothing less than the reification of life and human relationships (Horkheimer, 2012).

Taking into account Horkheimer's criticism, it seems clear that Weber was right in claiming that rationalization can be characterized as the major force of modernity and capitalism. His implicit criticism of rationalization suffocating human spontaneity is accurate: human freedom cannot be explained through means-to-end calculations, but must imply the sphere of values. Or more explicitly speaking, it has to be directed towards the sphere of values.

\section{Human freedom}

I am now left to explain what I mean by human freedom and how it can be conceived of. In general, I want to systematically differentiate between two dimensions of human freedom: (1) The possibility of human freedom and (2) the reality of human freedom. With the possibility of freedom (1), I refer to the justification of freedom within the sphere of theoretical philosophy. To frame my account in a coherent way within the history of ideas, I want to explain the possibility of freedom in connection to Kant's critical philosophy. What is of particular relevance for my account is to legitimize human freedom as Bedingung der Möglichkeit of practical philosophy. I hereby follow Kant in discerning the practical with the sphere of thought that starts with the assumption of human freedom. In his transcendental philosophy, Kant goes beyond the question of human freedom as free will or freedom of action. He discusses the question of freedom within the chapter of Antinomies of his transcendental dialectics.

Thesis: Causality in accordance with laws of nature is not the only one from which all the appearances of the world can be derived. It is also necessary to assume another causality through freedom in order to explain them.

Antithesis: There is no freedom, but everything in the world happens solely in accordance with laws of nature (Kant, 1999, A 444/B472-A445/B473).

The question of freedom in Kantian transcendental philosophy is a very particular kind of freedom, namely a freedom that is grounded in pure reason, a pure spontaneity 
that is independent from everything which is natural, and thus that is independent from all sense data. Transcendental freedom in Kantian terms is thus a necessary idea of the intelligible realm (the noumenal). It is but a pure idea whose objective reality is not to be proved either via natural laws, nor via any possible experience. Transcendental freedom can thus hardly ever be exhaustively understood, because we have no experiential reference to what we mean by freedom, when we think of the grounds of freedom on transcendental terms. For pure reason, freedom is consequently to be conceived of as a regulative idea of reason - for, on the one hand, thinking on the grounds of freedom is necessary for reason not to contradict itself but, on the other hand, it remains closed off from our substantial understanding.

In fact, Kant's antithesis of freedom can positively be resolved in a transcendental pragmatic way, viz. in terms of leaving behind the purity of reason. In other words: through the depiction of the unresolvable contradiction between laws of nature and spontaneity of the will can Kant justify freedom as Bedingung der Möglichkeit of all practical philosophy.

All human beings think of themselves, regarding the will, as free. Hence all judgments about actions come as if they ought to have happened even if they have not happened. Yet this freedom is no experiential concept, and also cannot be one, because freedom always remains even though experience shows the opposite of those requirements that are represented as necessary under the presupposition of freedom. On the other side, it is just as necessary that everything that happens should remain unexceptionably determined in accordance with natural laws, and this natural necessity is also not an experiential concept, precisely because it carries with it the concept of necessity, hence of a cognition a priori. But this concept of a nature is confirmed through experience and must unavoidably be presupposed if experience, i.e., cognition of objects of sense connected in accordance with universal laws, is to be possible. Hence freedom is only an idea of reason, whose objective reality is doubtful in itself, but nature is a concept of understanding that proves its reality from examples in experience and necessarily must prove it. Now although from this arises a dialectic of reason, since in regard to the will the freedom attributed to it appears to stand in contradiction with natural necessity; and at this fork in the road, with a speculative intent, reason finds the route of natural necessity much more traveled and useful than that of freedom: yet with a practical intent the footpath of freedom is the only one on which it is possible to make use of one's reason for deeds and omissions; hence it is just as impossible for the subtlest philosophy as for the commonest human reason to ratiocinate freedom away (Kant, 2002, pp. 455/456).

I consider Kant's reflections in pragmatic transcendental terms, as a necessary practical hypothesis of freedom. So, in other words, on the basis of the practical hypothesis, the contradiction between freedom (spontaneity) and nature (physical 
causation) is actually not to be conceived of as a contradiction, but as a coexistence of freedom and natural causation. Moving from the transcendental to the practical hypothesis of freedom is when the morality-condition becomes apparent: what is clear is that practical philosophical thinking is dependent on the practical hypothesis, because we could not possibly give up the idea of freedom without running into serious philosophical issues: it would encompass the loss of the capacity of moral reflectivity and moral responsibility. The consequences that would be generated from such denial of practical freedom would go beyond our capacities to reasonably fathom: for the philosophy of law, the practice of law and political philosophy are dependent on the precondition of human freedom.

Taking for granted what has been said, we can understand freedom as a precondition for practical thinking. However, what remains open is the explanation of the reality of freedom (2). And as the reality of freedom is concerned, we need to step further. For coming closer to an understanding of the reality of freedom, we need to evaluate further human responsiveness to reasons. Clustering these first reflections on the reality of freedom, we can consequently formulate a thesis for the reality of freedom:

The reality of freedom can be explained through the fact that human beings are rational animals that in general act for and out of reason(s).

To explain this thesis, I will take two steps. First, I will explain the concept of human agency and, second, I will explain what I understand by an action for and out of reason(s). What is human agency? Human agency is an aim directed activity; viz. it implies an intention of action. An intention is the will to reach an aim through a specific action. An intention involves deliberation about reason(s) for action. Thus, action is to be understood through intention, and the latter through the act of reasonable deliberation. Briefly structured, we can come to the following representation of an action:

1. Human agency is aim-directed activity.

2. Human agency implies action intention.

3. Human agency asks for a deliberation of reasons for actions.

4. Human agency can be articulated through the questions: Why? (Why are you doing that?)

Thereupon, human agency is understood as a practical consequence of deliberation about reasons for action which is the ground of action intentionality. If an action is however interpreted in that way, what follows logically is the conceptualization of the person having to be capable of articulating her action. Elizabeth Anscombe therefore concludes that the person acting needs to be able to consider her practical knowledge for explaining her action. As a logical necessity, practical knowledge is thus being made explicit through acting out; or in Anscombe's terms: practical knowledge is exercised in the action (Anscombe, 1957). Having practical knowledge precedes a sound action. 
The connection of practical knowledge with acting for and out of reason(s) is thus implicit in Anscombes's conception of human agency. The person acting knows her reasons and because she knows them, they are good, or at least good enough to act accordingly. Practical knowledge, according to Anscombe, is therefore unconditionally connected with good reasons.

However, those reasons for acting need not be good in the highest normative sense. But if reasons are (or will be) reasons for acting for human beings, so at least they must be good in a weak sense, that is, they need to appear to be good. Just as much in line with the scholastic theorem: quidquid appetitur, appetitur sub specie boni -whatever is strived for is sought for something good- practical knowledge thus explains the reality of a complete human action for and out of reason(s). And as already stated, I take acting for reasons as the Bedingung der Möglichkeit of the reality of freedom.

With the illustration of the reality of freedom - based on the thesis that human beings are animals that generally act for and out of reason(s)-, we have expressed a fundamental anthropological description of human beings as free rational beings. Not because they are beings of pure reason, but because they can act for reasons. And when they do so, they realize human freedom. For human life exemplifies a rational life form, human beings can be part of the realm of reason and the realm of freedom.

Taking for granted the anthropological assumptions, it is not only plausible and meaningful to argue in favor of the reality of freedom; it is rather a normative postulate. The normative conclusion can be articulated in the following way: we are and will be free and rational beings and should acknowledge one another as such. Why the anthropological assumption involves a normative conclusion can be explained through simple life-world reflections. For if we do not foster and normatively appeal to ourselves as human beings to live up to us being rational and free, we impoverish our normative standards of human beings. This is already potentially dangerous within the private realm of human life-worlds, but if that happens within the public spheres, what we can perceive is a public loss of normative orientation and measurement.

\section{Loss of value rationality as loss of freedom}

As I have stated drawing back on Anscombe, I take acting for reasons as the Bedingung der Möglichkeit of the reality of freedom. For freedom to be real, we need not always act out of reasons that are moral; we also do realize freedom when we act, trying to instrumentally achieve something. Therefore, we can conclude that we do realize freedom when we act for instrumental reasons. Yet, realizing human freedom is not exhausted in instrumental rationality. For understanding freedom comprehensively, we must include the importance of human values. Therefore, we need to differentiate between (a) value-rational acting and (b) instrumentally rational acting. 
(a) When people follow value-rational acting, they are authors of their aims, selfdetermining the ends of their actions. As Weber defined acting value rational, he thought of an actor, who is "determined by a conscious belief in the value for its own sake some ethical, aesthetic, religious or other form of behavior, independently of its prospects of success." (Weber, 1978, p. 25) In other words, value-rational action presupposes normative judgements. The actor is not merely deliberating about how to do something, but deliberating why we should do something, and how we should do something. Acting value-rationally can thus be respectively translated: as acting for normative reasons. What do I imagine with saying that? An example of an actor orientating herself value rationally is given by Philippa Foot in her monograph Natural Goodness (2001). There she presents an example given in Kropotkin's Memoirs of a Revolutionary. It represents the geographer and anthropologist Miklucho-Maklaj, who was sent by Russia in the 19th century to study the native people of the Malayan archipelago:

$[\mathrm{H}] \mathrm{e}$ had with him a native who had entered into his service on the express condition of never being photographed. The natives, as everyone knows, consider that something is taken out of them when their likeness is taken by photography. One day when the native was fast asleep, Maklay, who was collecting anthropological materials, confessed that he was awfully tempted to photograph his native, the more so as he was a typical representative of his tribe and would never have known that he had been photographed. But he remembered his agreement and refrained (Foot, 2001, p. 32).

As illustrated through the example, human action, that is directed towards a normative end (for example the value of a promise being given), means to act value rationally.

(b) Instrumental rational action has been defined by Weber as "being determined by expectations as to the behavior of objects in the environment and of other human beings; these expectations are used as "conditions" or "means" for the attainment of the actor's own rationality pursued and calculated ends" (Weber, 1978, pp. 24-25). Otherwise said, acting instrumental rational action implies that rationality is used as an instrument to achieve subjective ends. The action-determining reason is not to be understood as a normative value, but as one that succeeds a subjective criterion for utility. Let's take up the given example once again. One could easily imagine a scenario where the promise is being broken, for example in the illustrated situation. Presuming an instrumentally rational analysis, we could conclude that even if Miklucho-Maklaj had broken the promise and taken a picture, no one would have been hurt (as it is simply highly implausible that the Malayan had ever found out about breaking the promise). The utility, however (for anthropology, as well as for Maklaj himself), would have been maximized. Yet, even if Maklaj would have been able to achieve fame, his moral esteem would have been much lower.

Hence, it is this normative value of human interaction that brings forth the importance and specific dignity of value rational human action. In a world of rational totality, where the realization of human freedom is reduced to instrumentally rational 
human action, people would not only be instrumentalizing themselves reciprocally, but also evaluating their lives through drawing on cost-benefit equations. In a capitalistic organized world, it is highly important to come back to the importance of value-rational action, if we do not want to live in a world of means.

Value rational human action is central to normative liability. As Philippa Foot has shown, it can be illustrated through this very central human capability of promising. For value rational human action being an illustration of a normative realization of freedom, freedom is not to be understood as a mere multiplication of means. As exemplified, self-interest is undermining normative human interaction as well as normative bonds among people-bonds that are necessary for people living together on the grounds of freedom. Centering valuerationality as an important aspect of the realization of human freedom is to be understood as an important part of arguing for a critical theory of freedom, underlining the fact that freedom is neither exhausted in calculability, nor is it a simple metaphysical phenomenon, but something to be realized. In a political community organized around capitalism, centering value rational human action is an even more important aspect of a critical theory of freedom, for as capitalism validates instrumental behavior, instrumentality is colonizing value rational human action; a colonization that entails implicit devaluation of value-rational action, reducing human interaction to reciprocal instrumentalization. Value rational thinking and acting, thus, is more than an analytical consequence; it actually represents an emancipatory impetus. If the entanglement of modern life with capitalist structures undermines human freedom and renders it short of meaning, the essential consequence articulated by a critical theory of freedom is the normative claim to cultivate forms of thinking and action that go beyond the instrumental paradigm and towards a value-orientation, underpinning the end of freedom for all.

\section{References}

Anscombe, G. E. M. (1958). Modern Moral Philosophy. Philosophy, 33(124), 1-19. http://doi.org/10.1017/S000318191000037943

Anscombe, G.E.M. (1981). Metaphysics and the Philosophy of Mind (Collected Philosophical Papers, Vol. 2.). Oxford University Press.

Anscombe, G.E.M. (1981). Ethics, Religion and Politics (Collected Philosophical Papers, Vol. 3). Oxford University Press.

Bonefeld, W. (2020). Capital Par Excellence: On Money as an obscure thing. Estudios de Filosofía, 62, 33-56. https://doi.org/10.17533/udea.ef.n62a03

Del Aguila Marchena, L. (2020). Crítica marxiana de la igualdad en la ciudadanía moderna. Estudios de Filosofía 62, 11-32. https://doi.org/10.17533/udea.ef.n62a02

Foot, P. (2001). Natural Goodness. Oxford University Press. https://doi.org/10.1093/0198235089.001.0001 
Gewirth, A. (1978). Reason and Morality. University of Chicago Press.

Habermas, J. (1981). Theorie des kommunikativen Handelns. Band 1. Handlungsrationalität und gesellschaftliche Rationalisierung. Suhrkamp.

Habermas, J. (1982). Theorie des kommunikativen Handelns. Band 2. Zur Kritik der funktionalistischen Vernunft. Suhrkamp.

Horkheimer, M. (1937). Zur Anthropologie des bürgerlichen Zeitalters. Sieben Aufsätze von Max Horkheimer aus der Zeitschrift für Sozialforschung. Kohlhammer.

Horkheimer, M. (1972). Critical Theory. Selected Essays (Matthew J. O'Connell, Trans.). Continuum Publishing.

Horkheimer, M. (2004). Eclipse of reason. Continuum.

Horkheimer, M. (2007). Zur Kritik der instrumentellen Vernunft. Übersetzt von Alfred Schmidt. Fischer Taschenbuch.

Horkheimer, M. (2012). Critique of instrumental reason (J. O'Conell and others, Trans). Verso.

Illies, C. (2003). The Grounds of Ethical Judgement. New transcendental arguments in Moral Philosophy. Oxford University Press. https://doi.org/10.1093/acprof:oso/9780198238324.001.0001

Kant, I. (1974). Kritik der reinen Vernunft (Band 3 und 4). Suhrkamp (KrV).

Kant, I. (1974). Kritik der Urteilskraft (Band 10). Suhrkamp (KdU).

Kant, I. (1977). Metaphysik der Sitten (Band 8). Suhrkamp (MS).

Kant, I. (1999). Critique of Pure Reason. In P. Guyer, \& A. W. Wood (Eds. \& Trans), The Cambridge Edition of the Works of Immanuel Kant in Translation. Cambridge University Press.

Kant, I. (2000). Kritik der praktischen Vernunft. Grundlegung zur Metaphysik der Sitten (Band 7). Suhrkamp (KpV).

Kant, I. (2002). Groundwork for the Metaphysics of Morals (Allen W. Wood, Ed. \& Trans). Yale University Press.

Löwith, K. (2003). Max Weber and Karl Marx (T. Bottomore \& W. Outhwaite, Eds. \& Introduction). Taylor \& Francis e-Library.

Randall, C. (1980). Weber's Last Theory of Capitalism: A Systematization. American Sociological Review 45(6), 925-942. https://doi.org/10.2307/2094910

Weber, M. (1923). Wirtschaftsgeschichte. Duncker und Humblot.

Weber, M. (1950). General Economic History (Frank H. Knight, Trans). Illinois.

Weber, M. (1972). Wirtschaft und Gesellschaft. Grundriss der verstehenden Soziologie. Mohr und Siebeck.

Weber, M. (1978). Economy and Society. An outline for interpretative Sociology (G. Roth \& C. Wittich, Eds. \& Trans). University of California Press.

Weber, M. (2005). The protestant Ethic and the Spirit of Capitalism. (T. Parsons, Trans.). Routledge. https://doi.org/10.4324/9780203995808

Weber, M. (2006). Die protestantische Ethik und der Geist des Kapitalismus. Beck. 